\title{
FILE SHARING SERVER MENGGUNAKAN SAMBA SERVER DAN LINUX UBUNTU 12.04 SERVER
}

\author{
Andi Nugroho'), Yopi Handrianto ${ }^{2)}$ \\ ${ }^{1)}$ Program Studi Sistem Informasi \\ Universitas Mercubuana \\ J1. Meruya Selatan No.1 Jakarta Barat \\ andi.nugroho@mercubuana.ac.id \\ 2) Program Studi Komputerisasi Akuntansi \\ AMIK BSI Bandung \\ Jl. Sekolah Internasional No. 1-6 Antapani Bandung \\ yopi.yph@bsi.ac.id
}

\begin{abstract}
Data storage on server laboratory at the computer science when needed.It was because application that progressively and document required was handled by more than one person. Currently there are 6 class space the laboratory contained 30 units of computer in each room. All the time, Laboran (person who manage and work in a laboratory) have to bring harddrive external if you want to install application needed for each the lab, but during this laboran has only two external hard drive. This condition resulted in the process of installation application in the laboratory require a long time. In addition, every month laboran have to make recapitulation contract for 22 person laboratory's assistant. Now, to make contract assistant in the lab, laboran have to open one of the workstations that is in the fasilkom's laboratory. This can slow performance, because laboran have to coming into the fasilkom's laboratory. By the presence of the problems mentioned above, then built a file sharing that is used to hold the application of which is required in the entire room of Fasilkom's laboratory. In addition, a file sharing this can be used to speed up the emoluments of the preparation of reports on the whole lab assistant that until now had been stored luminance space laboratory so that laboran no need to use more external hard disk in installation perform the process of application by opening the Samba through Windows Server Explorer. It is also the case to compile the report honorarium of the lab's assistant, laboran enough to use of a file sharing fastly. A file sharing development is using the Linux Ubuntu operating system Version 12.04 and the application of the Samba Servers the Samba to connect storage a file that is in linux so that it can be opened in a windows or linux operating system based.
\end{abstract}

Keywords : Computer Lab, File Sharing Server, Linux Ubuntu, Samba Server.

\section{PENDAHULUAN}

Teknologi komputer saat ini semakin berkembang, dahulu jika akan mengirim data dari satu komputer ke komputer yang lainnya dibutuhkan media penyimpanan sementara seperti Disket, USB-Drive, dan Compact Disk atau DVD. Namun dengan adanya client dan server alat-alat tersebut diatas sudah tidak digunakan dengan maksimal lagi karena untuk mengirimkan data kita cukup dengan menggunakan file server dan dari file server data yang dikonsumsi untuk umum dapat didownload maupun dimanipulasi pada data di server tersebut. Hal ini membuat pengguna komputer tidak menggunakan media penyimpanan lagi untuk bertukar informasi dari komputer satu ke komputer yang lainnya.

Penyimpanan data pada server pada lingkungan Laboratorium Fakultas Ilmu Komputer Universitas Mercubuana pada saat ini sangat dibutuhkan dikarenakan aplikasi yang semakin beragam dan dokumen yang dibutuhkan juga tidak hanya diproses oleh 1 (satu) orang. Ruang Laboratorium Fakultas Ilmu Komputer terdapat 6 (enam) kelas yaitu ruang laboratorium C-115, C113, D206, D205, D204 dan D203 di seti ap ruang laboratorium tersebut rata-rata komputer 
yang ada pada setiap ruang laboratorium tersebut adalah 30 unit Personal Computer, dan di 1 (satu) laboratorium terdapat 2 (dua) orang Tenaga Laboran dan 22 (dua puluh dua) orang Assisten Laboratorium. Untuk saat ini, Tenaga Laboran akan membawa harddisk external jika ingin melakukan instalasi aplikasi yang dibutuhkan pada setiap laboratorium, untuk saat ini Laboran Laboratorium Fakultas Ilmu Komputer memiliki 2 (dua) buah harddisk external. Namun melihat dari kondisi saat ini dengan 2 (dua) buah harddisk external jika digunakan untuk melakukan instalasi komputer yang ada pada ruang laboratorium tersebut memerlukan waktu yang relatif lama karena harus bergantian dengan komputer yang lain untuk proses instalasi yang diperlukan oleh Laboran. Selain itu, Tenaga Laboran setiap bulannya harus melakukan rekapitulasi honorarium Assisten Laboratorium yang berjumlah 22 (dua puluh dua) orang. Saat ini untuk membuat rekapitulasi honorarium Assisten Laboratorium menggunakan komputer yang ada pada salah satu Laboran sehingga jika ingin membuat laporan honorarium harus membuka komputer Laboran tersebut. Hal ini tentunya memperlambat kinerja Tenaga Laboran dalam menyampaikan Rekapitulasi Honorarium Assisten Laboratorium kepada pihak Fakultas.

Dalam penelitian ini, keikutsertaan dalam pengembangan teknologi sangatlah dibutuhkan. Terlihat semakin berkembangnya teknologi, maka kontribusi penelitian ini diharapkan pusat data yang akan dibangun dapat mewujudkan Green Computing, kemudahan dalam bekerja dan kerapihan dalam penyimpanan data. Selain itu Penulis dapat mempelajari dan menambah wawasan teknologi pusat data, dimana semua data terpusat dalam sebuah server komputer kemudian yang mengakses data juga akan diberikan hak akses sehingga yang tidak berkepentingan tidak dapat mengakses data yang terdapat pada server.

Rumusan masalah dalam penelitian ini adalah : bagaimana membuat sebuah pusat data yang digunakan untuk menampung sejumlah aplikasi yang dibutuhkan laboratorium di fakultas ilmu komputer dan menampung data-data yang digunakan untuk membuat rekapitulasi honorarium asssisten laboratorium serta pembuatan dokumen lainnya yang diperlukan oleh pihak Laboran.

Adapun tujuan dari penelitian ini adalah : a. Data dalam server dapat digunakan sesuai dengan hak akses user yang diberikan oleh Admin Server.

b. Pembuatan rekapitulasi honorarium Assisten Laboratorium tidak hanya terpusat di satu komputer saja, tetapi dapat diakses oleh Tim Laboran diseluruh Laboratorium lain di fakultas ilmu komputer.

c. Meminimalkan penggunaan harddisk external yang berlebihan agar virus tidak dapat menyebar ke komputer yang akan dilakukan proses instalasi.

d. Memberikan hak akses untuk mengakses data kepada user, khususnya seluruh Laboran di laboratorium fakultas ilmu komputer.

\section{KAJIAN LITERATUR}

\section{A. File Server}

File Server adalah sebuah komputer yang dikhususkan untuk menyimpan file-file data yang dipergunakan oleh user yang komputernya terhubung pada suatu Local Area Network (Fadli, 2012). Pada jaringan komputer dengan sistem File Server, penempatan file-file seluruhnya dipusatkan pada File Server tersebut. Apabila ada komputer user yang rusak karena virus, maka data-data tetap aman tersimpan pada server.

Dengan demikian, faktor risiko penyalahgunaan data juga dapat di-liminasi Pada sistem ini, masingmasing pengguna akan mendapatkan Username dan Password yang harus dimasukkan pada waktu mengakses file/data pada File Server. Username dan Password tersebut yang berfungsi sebagai validasi hak mengakses datadata pada File Server.

Karena seluruh data-data penting ditempatkan pada server, maka biasanya spesifikasi komputer Server tersebut adalah harus lebih tinggi dari komputer lainnya, terutama pada media menyimpanan (harddisk) yang harus yang besar File Server yang menggunakan Linux sebagai Sistem Operasi, cenderung lebih handal terhadap serangan virus. Karena sampai saat ini belum ada virus yang mematikan atau berbahaya untuk Linux. Sebenarnya, dengan di-update-nya Sistem Operasi Linux maka ancaman virus-pun akan semakin berkurang bahkan tidak ada lagi. (Stalling, 2002). 


\section{B. Ubuntu 12.04 LTS}

Ubuntu 12.04 LTS sendiri adalah rilis Ubuntu yang ke-16 dan merupakan seri Long Term Support atau LTS yang ke 4. Apa itu Long Term Support ? LTS adalah versi Ubuntu yang di support lebih lama dari versi-versi Ubuntu yang biasa yaitu 4 tahun untuk versi Desktop dan 5 tahun untuk versi Server. Namun pada Ubuntu 12.04 ini, seri LTS akan sama-sama disupport selama 5 tahun baik itu untuk versi Desktop maupun Server. Seri LTS lebih ditujukan untuk kehandalan dan kestabilan sistem, sehingga sangat cocok digunakan untuk komputer server (Rahman, 2013).

\section{Samba Server}

Samba adalah sebuah software yang bekerja pada sistem operasi Linux, Unix, dan Windows yang menggunakan Protocol Network SMB (Server Message Block). Samba adalah sebuah protokol komunikasi data yang juga digunakan oleh Microsoft dan OS/2 untuk menampilkan fungsi jaringan Client-Server yang menyediakan sharing file dan printer serta tugas-tugas lainnya yang berhubungan. (Lasisi, 2012)

Samba mampu membagi file dengan komputer yang menggunakan sistem operasi Linux dan Unix Base dengan menggunakan sistem peer to peer selain berbagi file samba juga menjembatani fungsi-fungsi sistem Client-Server seperti penggunaan PDC (Primary Domain Control), DHCP (Dynamic Host Control Protocol), DNS (Domain Name Service), FTP (File Transfer Protocol), Web-Server, Mail-Server, TelNet, dan masih banyak lagi protokol yang lainnya.

Berikut ini merupakan fasilitas yang dapat dilakukan oleh Samba antara lain

a. Sharing file.

b. Sharing device dengan Samba seperti sharing printer.

c. Pengaturan user group dan security seperti konfigurasi Samba sebagai Primary Domain Control.

d. Mensupport Domain Name Service

e. Penggunaan File Transfer Protocol.

f. Konfigurasi Internet Gateway

Untuk dapat melakukan konfigurasi Samba Server, menggunakan aplikasi tambahan yaitu SWAT, aplikasi ini adalah sebuah aplikasi yang digunakan untuk mengkonfigurasi Samba Server melalui tampilan Web-Server. (Isminaldi, 2009).
Samba merupakan sebuah aplikasi yang dibuat dalam menyelesaikan sebuah permasalahan terkait dengan Windows dan Linux, karena selama ini kedua sistem operasi antara Windows dan Linux memiliki sebuah enviorement yang berbeda. Samba merupakan aplikasi open source yang dipergunakan untuk melakukan sharing data dan juga layanan printer dengan CIFS/SMB clients, komunikasi yang digunakan merupakan komunikasi jaringan dengan protokol yang dimiliki oleh Microsoft Windows dan juga dari sistem Windows yang lainnya. Berikut ini merupakan keuntungan dari menggunakan Samba antara lain : (Lasisi \& Ajagbe, 2012).

1. Otoritas pengaksesan data cukup satu, sehingga untuk mengakses data dari Windows cukup menggunakan otoritas yang sudah dibuat di Linux.

2. Dapat langsung mengakses data dari Windows ataupun dari Linux. Fleksible dalam melakukan sharing file dapat dilakukan dari Windows maupun Linux.

\section{Webmin}

Webmin adalah fasilitas pengelolaan service antarmuka berbasis web administrasi sistem untuk Unix. Bagi seorang sistem administrator, tentunya terbiasa dengan lingkungan berbasis teks untuk melakukan konfigurasi server servernya. Tentunya untuk mengedit file-file konfigurasi, dan tidak perlu lagi berhadapan dengan shell ,webmin bisa digunakan melalui browser apapun yang mendukung form, table, java dan CGI. Cukup dengan membuka browser, webmin dapat men-setup account pengguna, Apache, DNS, file sharing dan banyak lagi. Webmin tidak lagi mempersulit administrator untuk mengedit file konfigurasi secara manual, seperti password dan memungkinkan mengelola sistem dari konsol atau dari jarak jauh. (Fadli, 2012)

\section{METODE PENELITIAN}

\section{Internetworking Development \& Design Life Cycle (NDLC)}

Saat ini dengan perkembangan perangkat teknologi informasi terutama dibidang networking telah menjadikan kebutuhan akan infrastruktur sangat tinggi yang membuat para vendor berlomba untuk membuat solusi terintegrasi. Tetapi tidak semua solusi yang diberikan atau ditawarkan oleh vendor sesuai dengan kebutuhan perusahaan, karena strategi bisnis 
perusahaan akan berbeda- beda sesuai dengan visi dan misi perusahaan. (Setiawan 2009) Namun dalam pengembangan jaringan akan mendapatkan tantangan tersendiri, langkah pertama adalah harus mengerti tentang internetworking requirement kita, karena unsur reliability dan internetworking harus tercapai. Berikut ini merupakan gambar dari Network Development Life Cycle (NDLC).

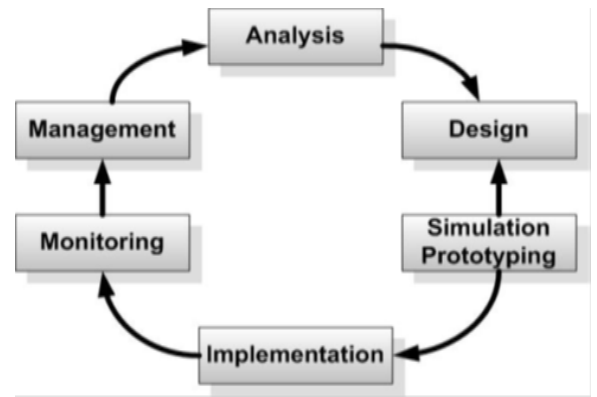

Sumber : (Setiawan, 2009)

\section{Gambar 1. Tahapan pada Network Development Life Cycle (NDLC)}

Dari gambar diatas bahwa setiap langkah-langkah dari NDLC dapat dijelaskan pada penjelasan berikut ini :

1. Analysis.

Tahap awal ini dilakukan analisa kebutuhan, analisa permasalahan yang muncul, analisa keinginan user dan analisa topologi/jaringan yang sudah ada saat ini. Metode yang biasa digunakan pada tahap ini diantaranya:

a. Wawancara, dilakukan dengan pihak terkait melibatkan dari struktur manajemen atas sampai ke level bawah/operator agar mendapatkan data yang konkrit dan lengkap.

b. Survey langsung kelapangan, pada tahap analisis juga biasanya dilakukan survey langsung kelapangan untuk mendapatkan hasil sesungguhnya dan gambaran seutuhnya sebelum masuk ke tahap design.

c. Membaca manual atau blueprint dokumentasi.

d. Menelaah setiap data yang didapat dari data-data sebelumnya.

\section{Design.}

Dari data-data yang didapatkan sebelumnya, tahap Design ini akan membuat gambar design topology jaringan interkoneksi yang akan dibangun.

\section{Simulation Prototype.}

Beberapa networker's akan membuat dalam bentuk simulasi dengan bantuan Tools khusus di bidang network seperti BOSON, PACKET TRACERT, NETSIM, dan sebagainya.

4. Implementation.

Pada tahapan ini akan memakan waktu lebih lama dari tahapan sebelumnya. Dalam implementasi networker's akan menerapkan semua yang telah direncanakan dan di design sebelumnya.

5. Monitoring.

Setelah implementasi tahapan monitoring merupakan tahapan yang penting, agar jaringan komputer dan komunikasi dapat berjalan sesuai dengan keinginan dan tujuan awal dari user pada tahap awal analisis.

6. Management.

Pada manajemen atau pengaturan, salah satu yang menjadi perhatian khusus adalah masalah Policy, kebijakan perlu dibuat untuk membuat/mengatur agar sistem yang telah dibangun dan berjalan dengan baik dapat berlangsung lama dan unsur reliability terjaga. Policy akan sangat tergantung dengan kebijakan level manajemen dan strategi bisnis perusahaan tersebut. IT sebisa mungkin harus dapat mendukung atau alignment dengan strategi bisnis perusahaan.

\section{PEMBAHASAN}

1. Konfigurasi Webmin

a. Login of Webmin

Tampilan halaman login pada url : https://localhost:10000 merupakan halaman user authentication untuk masuk kedalam sistem Webmin, berikut ini adalah tampilan dari halaman Login Webmin terlihat pada Gambar 2,

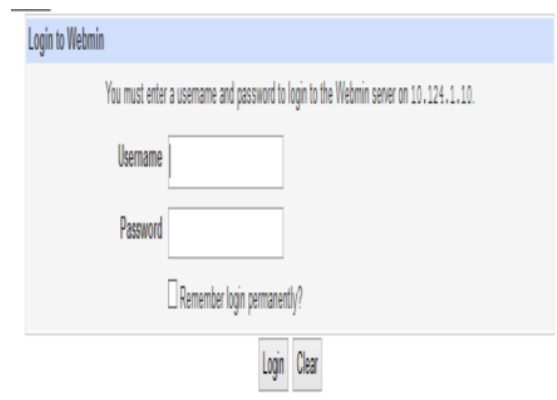

Sumber : Hasil Penelitian (2016)

Gambar 2. Halaman Login Webmin 


\section{b. Tampilan Halaman Utama}

Tampilan halaman utama dari Webmin, halaman utama ini digunakan untuk melihat kondisi server Linux, dapat melihat kapasitas memory yang terpakai dan kapasitas harddisk yang terpakai, serta dapat melihat menu disebelah kiri untuk melakukan konfigurasi server yang sudah ter-install di Webmin aplikasi. Untuk lebih jelasnya dapat dilihat seperti pada Gambar 3 berikut ini,

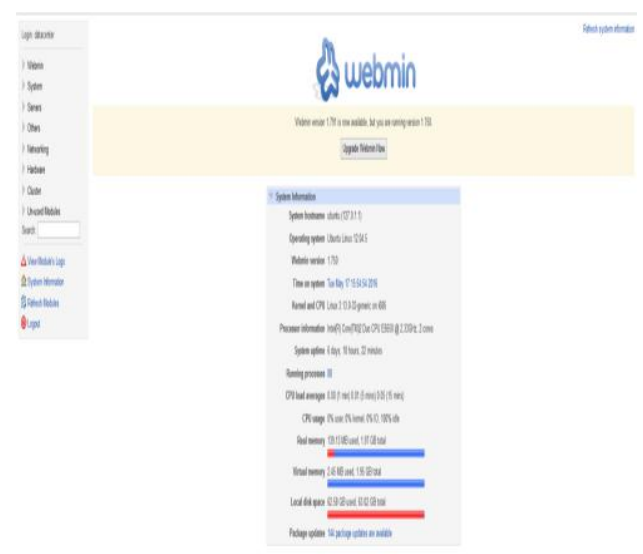

Sumber : Hasil Penelitian (2016)

\section{Gambar 3. Halaman Utama Webmin}

\section{c. Menu Menambah User Dalam Samba} Server

Pada menu menambah user kita dapat menambahkan user yang digunakan untuk mengakses data ke folder Samba Server. Menu tambah user ini dapat dikunjungi dengan memilih Menu System $\rightarrow$ User and Groups dan selanjutnya dapat dilihat pada Gambar 4 berikut ini,

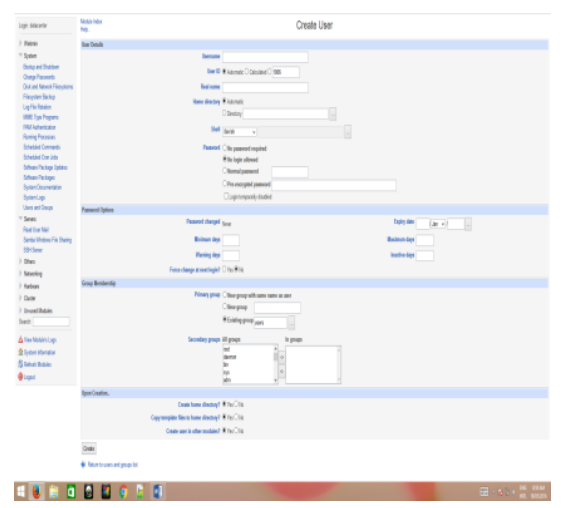

Sumber : Hasil Penelitian (2016)

\section{Gambar 4. Menambah Samba User dalam Webmin}

\section{d. Menu Membuat Folder Yang Akan Di Share}

Pada menu ini kita dapat membuat folder mana yang akan kita share atau bagikan, dimana pada share folder disini kita dapat menentukan user mana yang dapat mengakses folder tersebut, pada menu ini nantinya setelah dibuat kita juga dapat membatasi user yang dapat mengakses folder terebut, untuk dapat menambah folder yang akan dibagikan cukup dengan memilih Servers $\rightarrow$ Samba Windows File Sharing $\rightarrow$ Create a New File Share dan akan tampil seperti pada Gambar 5 berikut ini,

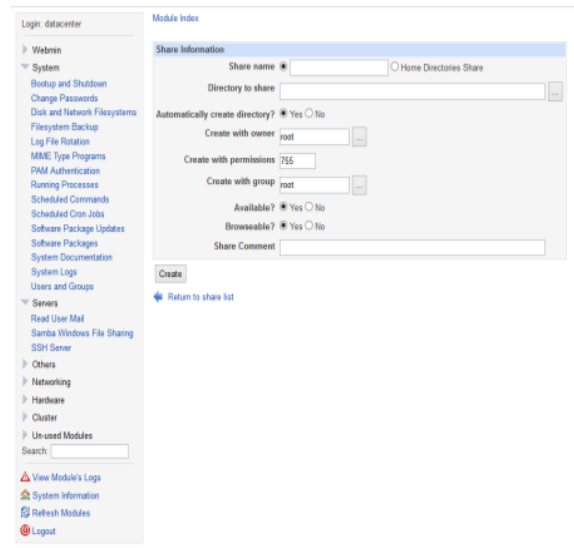

Sumber : Hasil Penelitian (2016)

\section{Gambar 5. Membuat Folder di Samba Server}

\section{e. Menu Edit Security}

Menu security ini bermanfaat untuk membatasi user yang membuka folder yang sudah dijelaskan pada penjelasan membuat menu folder, kita dapat menset siapa saja yang dapat membuka folder tersebut. Gambar 6 berikut ini menggambarkan folder data Assisten Laboratorium yang dishare hanya untuk user Assisten Laboratorium pilih : Servers $\rightarrow$ Samba Windows File Sharing $\rightarrow$ pilih Share Name setelah itu akan tampil seperti pada Gambar 6, 


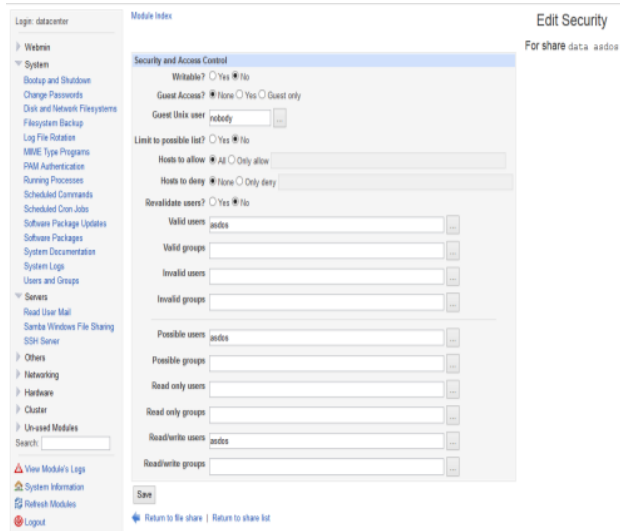

Sumber : Hasil Penelitian (2016)

\section{Gambar 6. Menu Edit Security}

\section{f. Membuka Folder Sharing Samba}

Cara untuk masuk dalam folder Samba Server dengan masuk ke Start Menu $\rightarrow$ pilih Run atau dengan menekan $C T R L+R$ seperti pada tampilan Gambar 7 berikut ini,

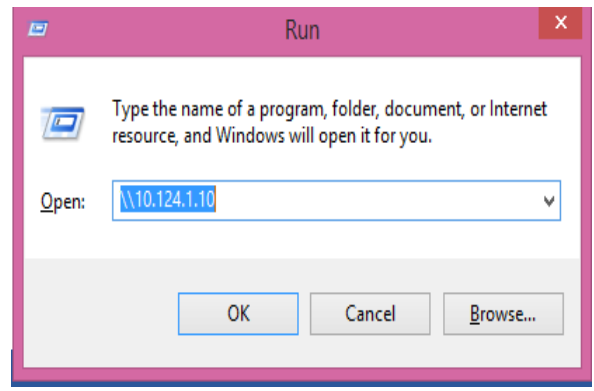

Sumber : Hasil Penelitian (2016)

Gambar 7. Membuka Folder Samba dari Windows

\section{Memasukan User Dan Password Samba}

Setelah memasukan alamat IP Address Server Samba, maka akan menampilkan username dan password, silakan masukan username dan password yang sudah dibuatkan tadi pada Server Webmin, artinya masukan username dan password yang sudah didaftarkan pada folder Samba Security. Untuk lebih jelasnya silahkan lihat Gambar 8 berikut ini,

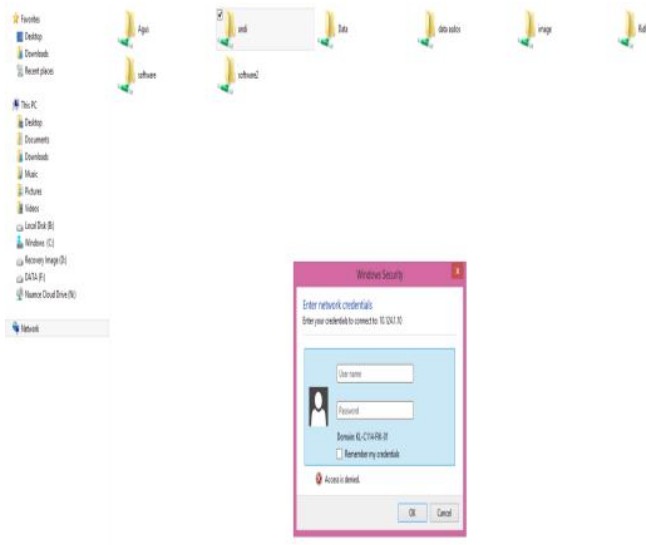

Sumber : Hasil Penelitian (2016)

\section{Gambar 8. Memasukan User Name dan Password Samba}

\section{PENUTUP}

Penelitian tentang file sharing server ini menghasilkan beberapa uraian sebagai berikut:

1. Dengan adanya Samba Server di Laboratorium Fakultas Ilmu Komputer Mercubuana, kinerja Assisten Laboratorium lebih efisien dalam melakukan instalasi aplikasi yang diperlukan di setiap Laboratorium Fasilkom karena tidak menggunakan hardisk external lagi, cukup dengan membuka Samba Server melalui Windows Explorer.

2. Dalam membuat Laporan Kinerja dan Rekapitulasi Honorarium Assisten Laboratorium, Tim Laboran dapat langsung membuat laporan pada file yang diletakan di Samba Server sehingga Koordinator Laboratorium dapat melihat langsung file sharing tersebut $\mathrm{di}$ komputer Koordinator Laboratorium tanpa harus menanyakan ke Tim Laboran lainnya apakah laporan sudah diselesaikan atau belum.

3. Dengan Samba Server, pekerjaan yang dilakukan oleh Tim dan Koordinator Laboran hasilnya dapat dikerjakan dengan konsep kolaborasi tanpa harus melakukan copy file terlebih dahulu ke masing-masing personal computer dimana setiap file dalam folder yang sudah tersedia tetap diproteksi oleh user previllage masing-masing.

4. Permintaan laporan ataupun kinerja tim laboran dan tugas tim laboran oleh pihak prodi sudah tidak perlu lagi menunggu tim laboran yang dituju, jika tim laboran atau koordinator berhalangan hadir dapat 
dibantu oleh tim laboran atau koordinator yang lainnya untuk mempersiapkan laporan. Karena semua file yang dibutuhkan akademik di share pada samba server dan folder di proteksi oleh user previllage masing-masing.

5. Dalam tahap pengembangannya, Samba Server dapat difasilitasi oleh sebuah VPN (Virtual Private Network) sehingga memungkinkan file dalam folder yang berada pada Samba Server internal memungkinkan untuk di akses diluar sehingga komunikasi data tetap dapat dilakukan tanpa dibatasi ruang dan waktu.

\section{DAFTAR PUSTAKA}

Fadli, Ferri (2012). Penerapan File Server Menggunakan Samba dan LDAP di U'budiyah Indonesia. Tugas Akhir.
Isminaldi (2009). Penerapan Sistem Samba Server Menggunakan Ubuntu 8.04 di SMA swasta insani Binjai. Tugas Akhir.

Lasisi Nojeem Ayodele, Ajagbe Akintunde Musibau (2012). Samba OPENLDAP: an evolution and insight, Internasional Journal of Computer Networks and Wireless Communications. ISSN : 22503501.Vol 2 No.3.

Rahman, Rizal (2013). Mahir Administrasi Server dan Router Linux Ubuntu 12.04 LTS, CC by SA.

Setiawan, Deris (2009), Fundamental Internetworking Development \& Design Life Cycle, Artikel Fasilkom Universitas Sriwijaya.

Stalling, W. 2002. Komunikasi Data dan Jaringan Komputer, Salemba Teknika. 